\title{
Study on Customers' Satisfaction on Mobile Banking Services
}

\author{
S. Loganathan', P. Balaji ${ }^{2 *}$, K. R. Ashok ${ }^{2}$ and S. Parameshwari \\ ${ }^{1}$ ODL, TNAU, Coimbatore-03, India \\ ${ }^{2}$ Department. of Agriculture and Rural Management, CARDS, TNAU, Coimbatore, India \\ *Corresponding author
}

\section{A B S T R A C T}

\section{Keywords}

Mobile banking service, Customer satisfaction, Anywhere Anytime Banking

\section{Article Info}

Accepted:

15 July 2020

Available Online:

10 August 2020
In 2019, 503 Public and Private Banks' customers are availing mobile banking services, irrespective of the mobile networks (RBI,2019). Mobile phone is a banking tool that consumers use for banking, payments, budgeting, shopping, etc. Today, banking industry focuses on internet technology which provides branchless banking services to the customers. This study was conducted in order to analyze the customer satisfaction of mobile banking services in Tamil Nadu. A questionnaire was developed and then distributed to customers of major mobile banking service providers in Tamil Nadu. Primary data were collected using Google form through online method, from 67 respondents, who are all account holder of public and private banks. The results show that majority of the respondents have 'extremely satisfied'/ 'satisfied' and opined the positive usage of mobile banking services provided by public and private banks in Tamil Nadu State.

\section{Introduction}

The spread of mobile technology across the globe is one of the most remarkable achievements in the last decades. Advancements in mobile technology have revolutionized almost every facet of society, from information to education, granting enhanced access to an ever-growing number of people. The changes have been catalysed by technological advancements, global commerce, competitiveness and customer demands can be stated as the important factors. As a result, banking services have quickly developed to adopt new delivery means to adapt to the changing commercial landscape. In order to meet customer expectations, banks compete with each other to have using new and innovative services to ensure a competitive edge (Shi and Lee 2008). Presently, the internet technology has brought a third revolution to this world-that is, mobile banking. The banking sector has been upgrading their services with the use of technology from time to time like introducing the ATM (Automatic Teller Machine), which took more than a decade to get popular while the phone and net banking took half as much as the ATM. Mobile banking, on the other hand, is the third era in technology of banking sector, after phone and net banking; comparatively, its growth was phenomenal 
when compared to the first two eras. With the adoption of mobile banking services, the banking sector is having a tremendous growth across the globe including India. Today, mobile banking often performed via SMS or the mobile internet but also using special programs that clients download to their mobile device. Some of the significant reasons that compel financial firms to provide mobile banking services are: it is appealing to customers, reduces costs per transactions, gaining revenue from service fees, enabling new service channels, and supporting future customers (Huili and Chunfang 2011).

The main reason why mobile banking scores over internet or phone banking is because it enables 'Anywhere Anytime Banking'. Customers don't need access to a computer terminal to access their bank accounts, now they can do so while on-the-go when waiting for the bus, travelling or when they are waiting for their orders to come through in a restaurant. Practically, mobile banking removes space and time limitations from banking activities. India, mobile banking service is a new theme and there is a strong need to analyse the critical aspects of this service. Public and private banks in this country are exploring this avenue to make their services more convenient for their customers. Hence, mobile banking service quality level and its effect on customer satisfaction is a crucial matter to investigate. Therefore, it is essential to analyze basic structure of mobile banking services offered by the banks, their evaluation of performance and customer satisfaction towards mobile banking services in Tamil Nadu State.

In the current competitive world, banks have to struggle their might to offer the best of the customer satisfaction through various innovative strategies in order to survive in the industry. This study would stand as a sincere attempt to evaluate customer satisfaction of mobile banking services in Tamil Nadu. The objective of the study is to examine the customer satisfaction of mobile banking users in Tamil Nadu. The study will help to examines mobile banking technologies, impact of mobile banking technologies and understand the purpose of using mobile banking service by measuring the level of user satisfaction. In this context, the purpose of this study is to find out the satisfaction level of the mobile banking users with special reference to Tamil Nadu has been undertaken.

Mobile banking (also known as M-Banking, m-banking, SMS Banking) is an application of mobile commerce which enables customers to access bank accounts through mobile devices such as a mobile phone or Personal Digital Assistant (PDA) to conduct and complete bank-related transactions such as checking account status, transferring money, balancing cheques and selling stocks (Kim, et. al., 2009; Tiwari and Buse, 2007). Mobile Banking can perform various functions like mini statement, checking of account history, SMS alerts, access to card statement, balance check, mobile recharge etc. via mobile phones (Vinayagamoorthy and Sankar, 2012). The use of mobile phones has facilitated the expansion of markets, social business, and public services in both developing and developed countries (Spence and Smith, 2010).

The high penetration of mobile phones across the strata of society makes it a natural tool for taking electronic banking to its next level. It is more than likely that Internet banking and mobile banking would exist as allies rather than competitors for each other. Mobile banking also allows customers to perform banking transactions 24 hours a day, 7 days a week, and 365 days a year (Eckhardt et al., 2009). Banks can utilize the time saved by the channel migration of customers to mobile banking for expansion of business through better marketing and sales activities. 


\section{Materials and Methods}

A sample size of 67 respondents from mobile banking users were collected through online, covering entire Tamil Nadu. A proposed sampling method was used to consciously selected customers who meet the criteria of having used mobile banking services for more than a years. The primary data were collected from July to September 2019. Descriptive statistics by percentages, figures and tables were generated from the software to establish relationship among variables. Descriptive statistics allow the researchers to present the data acquired in a structured, accurate and summarized manner. The analysis of data was done with the help of the statistical software of Statistical Package for Social Sciences (Version 20). The relevant information was obtained in a standard form using tables, frequencies and percentages to analyze and interpret the information.

\section{Results and Discussion}

Table 1 show that a slightly more than half of the respondents are female $52.20 \%$, which compared to the number of male $47.80 \%$. This implies that there is a fair distribution among respondents. seven categories, the customers from the age group of 18-25 years are the majority respondents for this study a response rate of $68.50 \%$, and $7.50 \%$ who belong to the age group of 26-30 years followed by others and majority of the respondents $50.80 \%$ are studied the UG Level.

Marital Status of the respondents shows that $73.10 \%$ of the respondents are fall under the unmarried status and the remaining 26.90\% belong to the married status. Current occupation of the respondents shows $55.20 \%$ of the respondents are students, while $23.90 \%$ of the respondents are from the Private sector followed by others. Monthly Income of the respondents shows that $47.80 \%$ of the respondents belong to the monthly income of below Rs. 10000/- and 17.90\% of the respondents belong to the monthly income of Rs. 10, 001 to Rs. 20, 000 followed by others.

\section{Bank details of the respondents}

From Table 2, it is clearly indicated that $47.70 \%$ of the respondents have their accounts in other banks, whereas $35.80 \%$ of the respondents have in SBI Bank followed by others.

\section{Mobile devices used to down load mobile banking app}

It can be referred from Table 3 that $95.50 \%$ of the respondents have downloaded the mobile banking app on their Android Mobile phone and about $4.50 \%$ of the respondents have downloaded the Mobile banking app on their Iphone. It can be inferred that Android Mobile phone is preferred by majority of the respondents, when compared Android Mobile Phone.

\section{Respondents' customer satisfaction of mobile banking services}

This section outlines the findings on customer satisfaction of mobile banking services

From the table 4, Balance checking were $92.50 \%$ of the respondents are either 'extremely satisfied' or 'satisfied' with checking account and $7.50 \%$ of the respondents are 'neutral'. Alert through SMS for balance $88.00 \%$ of the respondents are 'extremely satisfied/ 'satisfied', followed by $9.00 \%$ of the respondents who are 'neutral' and $3.00 \%$ of the respondents are 'dissatisfied' with the SMS alert. 
Table.1 Demographic characteristic of respondents

\begin{tabular}{|c|c|c|c|}
\hline Sl. No & Particulars & No of Respondents & Percentage $(\%)$ \\
\hline \multirow[t]{2}{*}{1.} & $\begin{array}{l}\text { Gender } \\
\text { a) Male } \\
\text { b) Female }\end{array}$ & $\begin{array}{l}32 \\
35\end{array}$ & $\begin{array}{l}47.80 \\
52.20\end{array}$ \\
\hline & Total & 67 & 100.00 \\
\hline \multirow[t]{2}{*}{2.} & $\begin{array}{l}\text { AGE } \\
\begin{array}{l}\text { a) } 18-25 \text { Years } \\
\text { b) } 26-30 \text { Years } \\
\text { c) } 31-35 \text { Years } \\
\text { d) } 36-40 \text { Years } \\
\text { e) } 41-50 \text { Years } \\
\text { f) } 51-60 \text { Years } \\
\text { g) Above } 61 \text { Years }\end{array}\end{array}$ & $\begin{array}{c}46 \\
5 \\
4 \\
4 \\
4 \\
3 \\
1\end{array}$ & $\begin{array}{c}68.50 \\
7.50 \\
6.00 \\
6.00 \\
6.00 \\
4.50 \\
1.50\end{array}$ \\
\hline & Total & 67 & 100.00 \\
\hline \multirow[t]{2}{*}{3.} & $\begin{array}{l}\text { Educational Qualification } \\
\text { a) UG level } \\
\text { b) PG level } \\
\text { c) Professional }\end{array}$ & $\begin{array}{c}34 \\
30 \\
3\end{array}$ & $\begin{array}{c}50.80 \\
44.80 \\
4.40\end{array}$ \\
\hline & (1) & 67 & 100.00 \\
\hline \multirow[t]{2}{*}{4.} & $\begin{array}{l}\text { Marital status } \\
\text { a) Married } \\
\text { b) Unmarried }\end{array}$ & $\begin{array}{l}18 \\
49\end{array}$ & $\begin{array}{l}26.90 \\
73.10\end{array}$ \\
\hline & Total & 67 & 100.00 \\
\hline \multirow[t]{2}{*}{5.} & $\begin{array}{l}\text { Current Occupation } \\
\text { a) Government Employee } \\
\text { b) Private Employee } \\
\text { c) Entrepreneur } \\
\text { d) Profession } \\
\text { e) Housewife } \\
\text { f) Student }\end{array}$ & $\begin{array}{c}7 \\
16 \\
1 \\
3 \\
3 \\
37\end{array}$ & $\begin{array}{c}10.40 \\
23.90 \\
1.50 \\
4.50 \\
4.50 \\
55.20\end{array}$ \\
\hline & Total & 67 & 100.00 \\
\hline \multirow[t]{2}{*}{6.} & $\begin{array}{l}\text { Monthly Income } \\
\text { a) Up to Rs. } 10,000 \\
\text { b) Rs. } 10,001 \text { to Rs. } 20,000 \\
\text { c) Rs. } 20,001 \text { to Rs. } 30,000 \\
\text { d) Rs. } 30,001 \text { to Rs. } 40,000 \\
\text { e) Rs. } 40,001 \text { to Rs. } 50,000 \\
\text { f) Rs. } 50,001 \text { and Above }\end{array}$ & $\begin{array}{c}32 \\
12 \\
10 \\
4 \\
3 \\
6\end{array}$ & $\begin{array}{c}47.80 \\
17.90 \\
14.90 \\
6.00 \\
4.40 \\
9.00\end{array}$ \\
\hline & Total & 67 & 100.00 \\
\hline
\end{tabular}


Table.2 Bank details of the respondents

\begin{tabular}{|c|l|c|c|}
\hline $\begin{array}{c}\text { SI. } \\
\text { No. }\end{array}$ & $\begin{array}{c}\text { Bank details of } \\
\text { the respondents }\end{array}$ & $\begin{array}{c}\text { No. of } \\
\text { Respondents }\end{array}$ & Percentage \\
\hline $\mathbf{1}$ & SBI Bank & 24 & $\mathbf{3 5 . 8 0}$ \\
\hline $\mathbf{2}$ & ICICI Bank & 2 & $\mathbf{3 . 0 0}$ \\
\hline $\mathbf{3}$ & HDFC Bank & 6 & $\mathbf{9 . 0 0}$ \\
\hline $\mathbf{4}$ & Axis Bank & 3 & $\mathbf{4 . 5 0}$ \\
\hline $\mathbf{5}$ & Other Bank & 32 & $\mathbf{4 7 . 7 0}$ \\
\hline & Total & $\mathbf{6 7}$ & $\mathbf{1 0 0 . 0 0}$ \\
\hline
\end{tabular}

Table.3 Mobile devices used to down load mobile banking app

\begin{tabular}{|c|l|c|c|}
\hline $\begin{array}{c}\text { Sl. } \\
\text { No. }\end{array}$ & \multicolumn{1}{|c|}{$\begin{array}{c}\text { Mobile devices used to down load } \\
\text { mobile banking app }\end{array}$} & $\begin{array}{c}\text { No. of } \\
\text { Respondents }\end{array}$ & Percentage \\
\hline 1 & Android Mobile Phone & 64 & $\mathbf{9 5 . 5 0}$ \\
\hline 2 & I phone & 3 & 4.50 \\
\hline & Total & $\mathbf{6 7}$ & $\mathbf{1 0 0 . 0 0}$ \\
\hline
\end{tabular}

Table.4 Mean, S.D., Frequency and Percentage of the Items in the Satisfaction Scale of Mobil Banking Services $(n=67)$

\begin{tabular}{|c|c|c|c|c|c|c|c|}
\hline & \multirow[t]{2}{*}{ Items } & \multicolumn{6}{|c|}{ Satisfaction of Mobile Banking Services } \\
\hline & & Mean & $\begin{array}{l}\text { S.D. } \\
(\%)\end{array}$ & $\begin{array}{c}\text { D } \\
(\%)\end{array}$ & $\begin{array}{r}\mathbf{N} \\
(\%)\end{array}$ & $\begin{array}{c}\mathrm{S} \\
(\%)\end{array}$ & $\begin{array}{c}\mathrm{ES} \\
(\%)\end{array}$ \\
\hline 1. & Basis of balance checking in the account. & 4.25 & $(0.58)$ & 0 & $\begin{array}{c}5 \\
(7.50)\end{array}$ & $\begin{array}{c}40 \\
(59.70)\end{array}$ & $\begin{array}{c}22 \\
(32.80)\end{array}$ \\
\hline 2. & Basis of alert through SMS for balance. & 4.17 & $(0.71)$ & $\begin{array}{c}2 \\
(3.00)\end{array}$ & $\begin{array}{c}6 \\
(9.00)\end{array}$ & $\begin{array}{c}37 \\
(55.20)\end{array}$ & $\begin{array}{c}22 \\
(32.80)\end{array}$ \\
\hline 3. & $\begin{array}{l}\text { Basis of PIN provision, change of PIN, blocking of } \\
\text { Card }\end{array}$ & 4.11 & $(0.76)$ & $\begin{array}{c}2 \\
(3.00)\end{array}$ & $\begin{array}{c}10 \\
(14.90)\end{array}$ & $\begin{array}{c}33 \\
(49.30)\end{array}$ & $\begin{array}{c}22 \\
(32.80)\end{array}$ \\
\hline 4. & Basis of transport or movie ticket & 4.08 & $(0.71)$ & $\begin{array}{c}1 \\
(1.50)\end{array}$ & $\begin{array}{c}11 \\
(16.40)\end{array}$ & $\begin{array}{c}36 \\
(53.70)\end{array}$ & $\begin{array}{c}19 \\
(28.40)\end{array}$ \\
\hline 5. & $\begin{array}{l}\text { Basis of mobile of DTH } \\
\text { Recharging }\end{array}$ & 4.07 & $(0.72)$ & $\begin{array}{c}1 \\
(1.50)\end{array}$ & $\begin{array}{c}12 \\
(17.90)\end{array}$ & $\begin{array}{c}35 \\
(52.20)\end{array}$ & $\begin{array}{c}19 \\
(28.40)\end{array}$ \\
\hline 6. & Basis of bill payment processing & 4.05 & $(0.71)$ & $\begin{array}{c}2 \\
(3.00)\end{array}$ & $\begin{array}{c}9 \\
(13.40)\end{array}$ & $\begin{array}{c}39 \\
(58.20)\end{array}$ & $\begin{array}{c}17 \\
(25.40)\end{array}$ \\
\hline 7. & Basis of status on 24 hours age Facilities & 4.04 & $(0.84)$ & $\begin{array}{c}4 \\
(6.00)\end{array}$ & $\begin{array}{c}10 \\
(14.90)\end{array}$ & $\begin{array}{c}32 \\
(47.80)\end{array}$ & $\begin{array}{c}21 \\
(31.30)\end{array}$ \\
\hline 8. & Basis of checking account history & 4.01 & $(0.70)$ & $\begin{array}{c}1 \\
(1.50)\end{array}$ & $\begin{array}{c}13 \\
(19.40)\end{array}$ & $\begin{array}{c}37 \\
(55.20)\end{array}$ & $\begin{array}{c}16 \\
(23.90)\end{array}$ \\
\hline 9. & $\begin{array}{l}\text { Basis of status on deposit at } \\
\text { Banking Agent }\end{array}$ & 3.77 & $(0.67)$ & 0 & $\begin{array}{c}24 \\
(35.80)\end{array}$ & $\begin{array}{c}34 \\
(50.80)\end{array}$ & $\begin{array}{c}9 \\
(13.40)\end{array}$ \\
\hline 10. & Basis of status on withdrawal at Banking & 3.68 & $(0.76)$ & $\begin{array}{c}3 \\
(4.50)\end{array}$ & $\begin{array}{c}24 \\
(35.80)\end{array}$ & $\begin{array}{c}31 \\
(46.30)\end{array}$ & $\begin{array}{c}9 \\
(13.40)\end{array}$ \\
\hline & Total & 3.85 & $(0.47)$ & & & & \\
\hline
\end{tabular}

Note: Figures in the Parentheses indicates Percentages

$\mathrm{D}=$ Dissatisfied, $\mathrm{N}=$ Neutral, $\mathrm{S}=$ Satisfied, ES = Extremely Satisfied 
It can be inferred that majority of the respondents $88.00 \%$ are 'extremely satisfied'/ 'satisfied' by getting 'alert through SMS for balance. Every mobile bank app is equipped to accommodate these requests such as PIN provision, Change of PIN and Blocking of cards in that $82.1 \%$ of the respondents are extremely satisfied'/'satisfied' with using mobile banking services, $14.90 \%$ of the respondents are 'neutral' and $3.00 \%$ of the respondents are 'dissatisfied'. Transport or Movie ticket booking ware $82.1 \%$ of the respondents are extremely satisfied'/'satisfied' with "Transport or Movie ticket booking" by using mobile banking services, $16.40 \%$ of the respondents are 'neutral' and $1.50 \%$ of the respondents are 'dissatisfied'. No respondent is 'extremely dissatisfied'. Recharge refers to usage of services after prior payment for a service, for example recharge of Prepaid mobile phone number and DTH (Direct to home) set top box connection (TV subscription Recharging) are commonly recharged by the customers. it can be observed that $80.60 \%$ of the respondents are 'extremely satisfied' / 'satisfied' with using mobile banking services, followed by 17.90 $\%$ of the respondents who are 'neutral'. Very few respondents $1.50 \%$ are 'dissatisfied' about this service. In Bill payment processing most of the respondents $83.60 \%$ are either 'extremely satisfied' or 'satisfied' with "PIN provision, followed by $13.40 \%$ of the respondents who are 'neutral' and only $3.00 \%$ of the respondents are 'dissatisfied'. It can be inferred that majority of the respondents 83.60\% are 'extremely satisfied' /'satisfied'. 24 Hours usage facility found that $79.10 \%$ of the respondents are 'extremely satisfied' / 'satisfied' with "24 Hours usage facility" of mobile banking service, $14.90 \%$ of the respondents are 'dissatisfied' with "24 Hours usage facility" of mobile banking service. $6.00 \%$ respondent is found 'extremely dissatisfied' with this service through the mobile banking app. It can be inferred that most of the respondents $79.10 \%$ are 'extremely satisfied' / 'satisfied' with "24 Hours usage facility". Checking account history $79.10 \%$ of the respondents 'extremely satisfied' or 'satisfied' with checking account history using mobile banking services, $19.40 \%$ of the respondents feel 'neutral' and the rest of the respondents $1.50 \%$ are 'dissatisfied'. Status on deposit at banking agent, it can be observed that $64.20 \%$ of the respondents are 'extremely satisfied' / 'satisfied' with using mobile banking services, followed by $35.80 \%$ of the respondents who are 'neutral'. There are no respondents in 'dissatisfied' about this service. Withdrawal and Deposit at banking agent shows that $59.70 \%$ of the respondents are 'either extremely satisfied' or 'satisfied', followed by $35.80 \%$ oftherespondentswhoare"neutral"and $4.50 \%$ oftherespondentsare 'dissatisfied' with the service of withdrawal at banking agent. It can be inferred that majority of the respondents $59.70 \%$ of the respondents are 'either extremely satisfied' or 'satisfied'.

Public and private banks should make indepth communication with their customers so that they can learn about the expectation of customers regarding the service quality dimensions. The survey should be made every year on customer satisfaction for making yearly comparison on service improvement and also analyzing the effect of this improvement on customer's perception and satisfaction. Public and private banks should educate, persuade and train mobile banking service agents to deal effectively with customers and solving their problems. The transaction must be secured and if any problem occurs then, it should be resolved as soon as possible.

In conclusion the current study focused on customer satisfaction of mobile banking services. From the above analysis, majority of the respondents are extremely satisfied / 
satisfied ones, because of reasons availability of mobile banking facilities such as checking account history, balance checking, mobile or DTH recharging, transport or movie ticket booking, cheque book request, status on cheque- stop payment on cheque, PIN provision- change of PIN-Blocking of cards, withdrawal at banking agent, deposit at banking agent ATM location, 24 hours usage facility and current needs of customers. Because the minimum respondents were only dissatisfied with the mobile banking services. The statistical mean scores was very high which indicated that majority of the respondents were satisfied with the mobile banking service of checking the balance of their account $($ Mean=4.25). The overall mean score (Mean=3.85) also revealed that the respondents were highly satisfied with all the mobile banking services. Therefore, this study results showed that majority of the respondents have 'extremely satisfied'/ 'satisfied' and opined the positive usage of mobile banking services provided by public and private banks in Tamil Nadu State.

\section{References}

Barnes, S.J. and Corbitt, B. (2003) Mobile Banking: Concept and Potential. International Journal Of Mobile Communications, 1, 273-288.

Eckhardt, A., Vaumer, S. and Weitzel, T. 2009 Who Influences Whom? Analyzing Workplace Reference Social Influence On It Adoption And Non
Adoption', Journal Of Infermation Technology, 24(1): 11-24.

Huili, Y, and Chunfang Z., 2011.'The Analysis Of Influencing Factors And Promotion Strategy For The Use Of Mobile Banking', Canadan Social Science, 7(2):60-63

Kim, G., Shin, B. And Lee, H.G. 2009,'Understanding Dynamics Between Initial Trust And Usage Intentions Of Mobile Baing', Information Systems Journal, 19(3): 283-311.

Lee, K., Lee, H. And Kim, S. 2007. Factors Influencing the Adoption Of Behaviour Of Mobile Banking: The South Korean Perspective. Journal Of Internet Banking \&Commerce, 12, 1-9.

Rbi 2019. According To A Payment And Settlement System In India: Vision2019-2021, Rbi Report.

Shi, W. And Lee.C.2008.Does Quality Of Alternatives Matter For Internet Banking? Int. J. Electronic Finance, Vol.2 (2):162-179.

Spence, R. And Smith, M.L. 200.Ict. Development and Poverty Reduction: Five Emerging Stories', Information Technologies and International Development, 6, 11-17.

Sunil K. M., and Durga P.S. 2013. Mobile Banking Adoption and Benefits Towards Customers Service', Modern Engineering Management Studies (Mems). 2(1), 2319-2526.

\section{How to cite this article:}

Loganathan, S., P. Balaji, K. R. Ashok and Parameshwari, S. 2020. Study on Customers' Satisfaction on Mobile Banking Services Int.J.Curr.Microbiol.App.Sci. 9(08): 1366-1372. doi: https://doi.org/10.20546/ijcmas.2020.908.155 